\title{
Neurotransmitter Modulation of Calcium Channels in Rat Sympathetic Neurons
}

\author{
Mark R. Plummer, Ann Rittenhouse, Max Kanevsky, and Peter Hess \\ Department of Cellular and Molecular Physiology, Program in Neuroscience, Harvard Medical School, Boston, \\ Massachusetts 02115
}

\begin{abstract}
Adrenergic, cholinergic, and a variety of peptide neurotransmitters are known to modulate Ca currents in peripheral neurons. Using a protocol that allows for simultaneous assessment of effects on dihydropyridine (DHP)-sensitive and DHP-insensitive current components, we compared the actions of norepinephrine (NE), bethanechol (BeCh), and neuropeptide $\mathrm{Y}$ (NPY) on Ca currents in neonatal rat superior cervical ganglion neurons. Here, we show that these transmitters selectively depress the activity of DHP-insensitive Ca channels. Intracellular application of GTP- $\gamma-S$, an activator of GTP-binding proteins, also exclusively affected the DHP-insensitive current, whereas 1,2-oleoylacetylglycerol (OAG), a protein kinase $\mathrm{C}$ (PKC) activator, depressed both the DHP-sensitive and DHP-insensitive currents. Pertussis toxin interrupted the coupling between NE and its effector, whereas three different inhibitors of PKC did not. Thus, we confirmed that the selective actions of the transmitters on Ca current appear to be mediated via GTP-binding proteins, but we found no evidence for direct involvement of PKC and conclude that the observed actions of OAG are distinct from those mediated by the neurotransmitters studied.
\end{abstract}

Depression of Ca currents in peripheral neurons by neurotransmitters is thought to constitute an important regulatory mechanism of synaptic transmission. While the block of $\mathrm{Ca}$ currents in sensory and sympathetic neurons by catecholaminergic, cholinergic, GABAergic, and peptidergic transmitters is well established (Dunlap and Fischbach, 1981; Forscher and Oxford, 1985; Dolphin and Scott, 1986; Marchetti et al., 1986; Gross and Macdonald, 1987; Wanke et al., 1987; Schofield and Ikeda, 1988; Walker et al., 1988; Grassi and Lux, 1989; Ikeda and Schofield, 1989; Lipscombe et al., 1989; Bley and Tsien, 1990; Schofield, 1990), in most cases the identity of the Ca channel types that serve as the target for the modulation remains unclear. By studying cells that contained only a single pharmacologically defined component of calcium current, Kasai and Aosaki (1989) showed that an adenosine analog selectively acted on dihydropyridine (DHP)-insensitive calcium channels. To distinguish between DHP-sensitive and -insensitive $\mathrm{Ca}$ channels in cells

Received Nuv. 12,1990; revised Jan. 24, 1991; accepted Feb. 27, 1991.

We thank Bruce Bean, Chinfei Chen, Emily Liman, and Daniela Pietrobon for helpful discussions. This work was supported by grants from NIH and the American Cancer Society and in part by the Markey Charitable Trust. M.K. was supported in part by the work-study program of Harvard University.

Correspondence should be addressed to Peter Hess, Department of Cellular and Molecular Physiology, Ilarvard Medical School, 25 Shattuck Street, Boston, MA 02115 .

Copyright (C) 1991 Society for Neuroscience $0270-6474 / 91 / 112339-10 \$ 03.00 / 0$ that contain multiple components of calcium current, we have used a protocol introduced by Plummer et al. (1989), and we show that adrenergic and cholinergic agonists and neuropeptide Y (NPY) act selectively on non-DHP-sensitive Ca channels in rat superior cervical ganglion (SCG) neurons.

There is general agreement that GTP-binding proteins are a necessary link between the activation of the receptors for ncurotransmitters and the reduction of Ca current (Holz et al., 1986; Dolphin and Scott, 1987; Hescheler et al., 1987; Wanke et al., 1987; Ewald et al., 1988a; Rosenthal et al., 1988; Kasai and Aosaki, 1989; McFadzean et al., 1989; Song et al., 1989). However, contradictory reports exist concerning the role of protein kinase $\mathrm{C}(\mathrm{PKC})$ in the receptor-effector coupling cascade (Rane and Dunlap, 1986; Ewald et al., 1988b; Gross and Macdonald, 1989; Hockberger et al., 1989; Kasai and Aosaki, 1989; Rane et al., 1989; Doerner et al., 1990; Foucart et al., 1990; Schroeder et al., 1990). We confirmed that the effects of both adrenergic and cholinergic agonists are mimicked by internally applied nonhydrolyzable GTP analogs and are abolished by pretreatment of cells with pertussis toxin (PTX). In contrast, we found that 1,2-oleoylacetylglycerol (OAG), a known activator of PKC, had effects clearly distinct from those of the neurotransmitters. OAG equally reduced both DHP- and non-DHP-sensitive currents and induced kinetic changes that could easily be distinguished from those mediated by the transmitters. In addition, incubation of neurons with the PKC inhibitor $\mathrm{H}-7$ (Hidaka et al., 1984), downregulation of PKC with the phorbol ester phorbol 12-myristate-13-acetate (TPA; Matthies et al., 1987), or intracellular dialysis for more than 30 min with a specific PKC inhibitor peptide (PKCI19-31; House and Kemp, 1987) failed to affect the responsiveness of $\mathrm{Ca}$ currents to norepinephrine (NE). Thus, we found no evidence for an obligatory role of PKC in the transmitter modulation of Ca currents in rat SCG, and our results strengthen the view that OAG can act on Ca channels (Hockberger et al., 1989) by a mechanism distinct from that used by neurotransmitters to downmodulate Ca channel current.

\section{Materials and Methods}

Cell culture. Sympathetic neurons were obtained from superior cervical ganglia of neonatal (1-3 d) rats and maintained in tissue culture for up to $24 \mathrm{hr}$. The dissociation procedure was based on a nonenzymatic method (Hawrot and Patterson, 1979) and produced cells that were free of processes. The cells were plated on poly-L-lysine coated glass coverslips in Dulbecco's modified Eagle's medium (DMEM) supplemented with $10 \%$ fetal calf serum (HyClone), $1 \%$ penicillin-streptomycin (Gibco), and NGF prepared from mouse salivary glands. For experiments that required $24 \mathrm{hr}$ of incubation with TPA, an enzymatic dissociation method was used because cells prepared in this way survive for longer times in tissue culture. The ganglia were cut into pieces, incubated in a 
Ca-free dispase/collagenase solution for 60-90 min, and then triturated and plated on coverslips coated with collagen (Vitrogen) in the supplemented DMEM.

Patch-clamp recordings. Whole-cell recordings were obtained with standard techniques (Hamill et al., 1981). The currents were recorded with a List EPC-7 or Dagan 3900 amplifier, digitized at $5-20 \mathrm{kHz}$ with a PDP-11/73 computer running RAsic-23 (INDEC), filtered at $1-5 \mathrm{kHz}$ (Frequency Devices eight-pole bessel filter), depending on sampling frequency, and stored for subsequent analysis. The pipette solution contained (in mM) 123 Cs-aspartate, 10 CsEGT $\Lambda, 10 \mathrm{HEPES}-\mathrm{CsOH}, 5$ $\mathrm{MgCl}, 4 \mathrm{ATP}$, and $0.4 \mathrm{GTP}(\mathrm{pH} 7.5)$. The recording solution contained (in $\mathrm{mM}$ ) $20 \mathrm{Ba}$-acetate (BaAc), 135 tetraethylammonium (TEA)-aspartate or $N$-methyl-D-glucamine (NMG)-aspartate, $10 \mathrm{HEPES}$, and 0.001 tetrodotoxin (TTX). The $\mathrm{pH}$ was adjusted to 7.5 with either TEA-OH or $\mathrm{CsOH}$. Pipette resistances ranged from 1 to $2 \mathrm{M} \Omega$, and series resistances (after compensation) ranged from 2 to $4 \mathrm{M} \Omega$. All recordings were made at room temperature $\left(20-23^{\circ} \mathrm{C}\right)$. Membrane voltage was held at $-90 \mathrm{mV}$ for the duration of the recording session, and command pulses were delivered at 4-5-sec intervals to the levels indicated in the text. Linear leak and capacitative currents (measured with hyperpolarizing pulses to $1 / 10$ the test potential) were subtracted prior to analysis and from all records shown. Currents were measured as the average of 10 sampling points around the maximum value found within a small time interval after the onset of the test pulse (peak current) or after a repolarization step (tail current).

Chemicals. Norepinephrine (Calbiochem), acetylcholine, bethanechol $(\mathrm{BeCh}$ ), clonidine (all Sigma), OAG (Calbiochem and ICN Biochemicals), and neuropeptide $Y$ (Bachem) were bath applied at the concentrations indicated in the text. The $\omega$-conotoxin ( $\omega$-CgTx; Peninsula Labs) was applied directly to cells by pressure injection from a glass micropipette. All substances (except OAG) were prepared as stocks in distilled water and diluted into the recording solution. OAG was prepared as a 50-mM stock in either dimethyl sulfoxide (DMSO) or chloroform. This stock was then diluted 1:1000 into the external recording solution. In the case of DMSO, an equivalent amount of DMSO was added to the drug-free solution. In the case of chloroform, the chloroform was allowed to evaporate before addition of the OAG to the recording solution (Rane and Dunlap, 1986). In both cases, the OAG solution was sonicated extensively before use. In all measurements of tail currents, $(+)-(S)$ 202-791 (a gift of Dr. Hof, Sandoz, Co.), prepared as a 3-mm stock in $100 \%$ ethanol, was present at $1 \mu \mathrm{M}$ in the control and drug-containing solutions. Intracellular application of GTP- $\gamma$-S (Boehringer-Mannheim) was accomplished by substitution of $100 \mu_{\mathrm{M}}$ GTP- $\gamma$-S for the GTP in the pipette solution. For inhibition of protein kinase C, 1-(5-isoquinolinylsulfonyl)-2-sulfonylpiperazine (H-7) and phorbol 12-myristate-13acetate (TPA; both from Sigma) were prepared as stocks in DMSO and diluted 1:1000 and 1:2000, respectively, into media for preincubation ( $1 \mathrm{hr}$ for $\mathrm{H}-7,24 \mathrm{hr}$ for TPA). Control solutions contained a comparable amount of DMSO. $\mathrm{H}-7$ was included in the recording solutions during tests of NE effects. Preparation and intracellular application of the protein kinase C inhibitor PKCI19-31 (Peninsula Labs) was performed as described by Rane et al. (1989).

\section{Results}

Selective inhibition of N-type currents by $N E, B e C h$, and NPY Figure $1 \mathrm{~A}$ compares the effects of the muscarinic agonist $\mathrm{BeCh}$ and the adrenergic agonist NE on two SCG neurons. At a concentration of $100 \mu \mathrm{M}$, both agonists inhibit the whole-cell Ba currents by roughly the same amount. The effects occur rapidly and are completely reversible (Fig. $1 B$ ). Addition of NE in the presence of BeCh further decreases the current, but the effects are not completely additive (Fig. $1 B$ ). A more quantitative analysis of the relative inhibition produced by each agonist will be discussed in a later section (see Fig. 8).

The whole-cell Ba current in rat SCG neurons is carried by two types of Ca channels (Plummer et al., 1989), a DHP-sensitive noninactivating channel (L-type $\mathrm{Ca}$ channel) and a slowly and incompletely inactivating non-DHP-scnsitive channel ( $\mathrm{N}$ type $\mathrm{Ca}$ channel). Neither the kinetic changes induced by the transmitters (Fig. 1A) nor the effects on the current-voltage relationship (Fig. $1 C$ ) allow an unequivocal identification of the $\mathrm{Ca}$ channel type(s) inhibited by the transmitters. In order to separate DHP- from non-DHP-sensitive Ca current components, we used the DHP-agonist $(+)-(S)-202-791$ to produce a slowly decaying component of whole-cell tail current that could be ascribed to L-type Ca channels alone (Plummer et al., 1989; Bley and Tsien, 1990). Figure 2 shows such an experiment, in which NE was added in the presence of $1 \mu \mathrm{M}(+)-(S)$-202-791. As in the absence of the DHP agonist, NE reversibly reduced the peak currents $(42.1 \pm 2.6 \%$ reduction, mean $\pm \mathrm{SEM} ; n=$ 26). However, the transmitter only blocked the rapidly decaying component of tail current (see arrows in Fig. $2 B$ ) and had no effect on the slowly decaying component of tail current (2.31 \pm $1.63 \%$ reduction; $n=11$ ). The interpretation that the slow component of tail current is carried exclusively by DHP-sensitive L-type channels is validated by the current traces shown in the lower panel of Figure $2 B$ : the slow component of tail current vanishes after washout of the DHP agonist. The small decrease of the peak current upon washout of $(+)-(S)-202-791$ is consistent with previous evidence that at a test potential of +20 $\mathrm{mV}$ the majority of the inward $\mathrm{Ba}$ current is carried by nonDHP-sensitive N-type channels (Jones and Marks, 1989; Plummer et al., 1989).

One potential problem with these experiments was the possibility that the $(+)-(S)-202-791$ interfered with the action of NE on the L-type channel. To control for this, we tested for a response to $\mathrm{NE}$ under conditions designed to isolate the L-type current without the use of DHP (Fig. 3). At a holding potential of $-50 \mathrm{mV}$, originally reported to inactivate largely the N-type current (Fox et al., 1987a,b), a moderate reduction in current was produced by addition of $100 \mu \mathrm{M}$ NE $(32.2 \pm 3.35 \% ; n=7)$. However, following application of $\omega$-CgTx, a specific blocker of only N-type channels (Aosaki and Kasai, 1989; Plummer et al., 1989), a major portion of the current available at a holding potential of $-50 \mathrm{mV}$ was eliminated. Addition of NE produced no reduction of the L-type current remaining after $\omega$-CgTx block $(1.39 \pm 0.52 \%, n=7)$, indicating that the DHP agonist did not mask an effect of NE. These experiments also show that changing the holding potential to $-50 \mathrm{mV}$ was not sufficient to inactivate $\mathrm{N}$-type current completely and therefore was not an adequate means of testing for selective effects of substances on L-type calcium channels.

Further experiments with the tail-current protocol using the muscarinic agonist $\mathrm{BeCh}$ produced results similar to those obtained with NE. In the presence of (+)-(S)-202-791, BeCh reduced peak inward Ba currents by $31.5 \pm 3.3 \%(n=24)$. In contrast, the average reduction of slow tail currents carried by L-type channels was $3.76 \pm 1.7 \%(n=8)$. Thus, we conclude that $\mathrm{BeCh}$, like NE, acts selectively on N-type channels.

Figure 4 extends our findings to NPY, a transmitter of particular interest because it is present in dense-core synaptic vesicles in sympathetic neurons (Fried et al., 1985a,b), and because it has been claimed to inhibit both L-type and N-type Ca channels in dorsal root ganglion (DRG) neurons (Walker et al., 1988). However, as with adrenergic and cholinergic transmitters, 100 nм NPY reversibly inhibited the peak current at $+10 \mathrm{mV}(30.7$ $\pm 3.1 \% ; n=7$ ) and the rapidly deactivating N-type current tails (see arrows in Fig. 4), but failed to block the slow tails carried by L-type currents (average change, $+0.29 \pm 1.75 \% ; n=7$ ).

\section{GTP-binding proteins mediate transmitter actions}

Holz et al. (1986) first recognized that the actions of NE on neuronal $\mathrm{Ca}$ currents are mediated by PTX-sensitive GTP-binding proteins, a finding that has since been extended to include 
A1

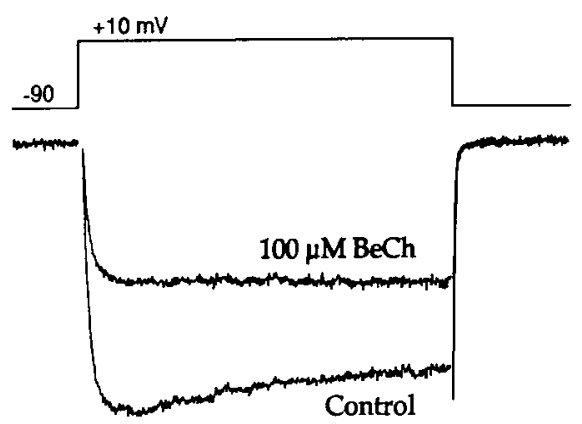

A2

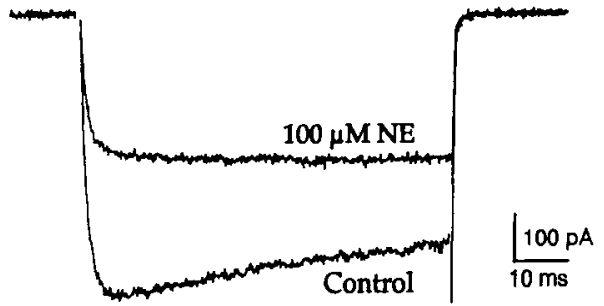

B
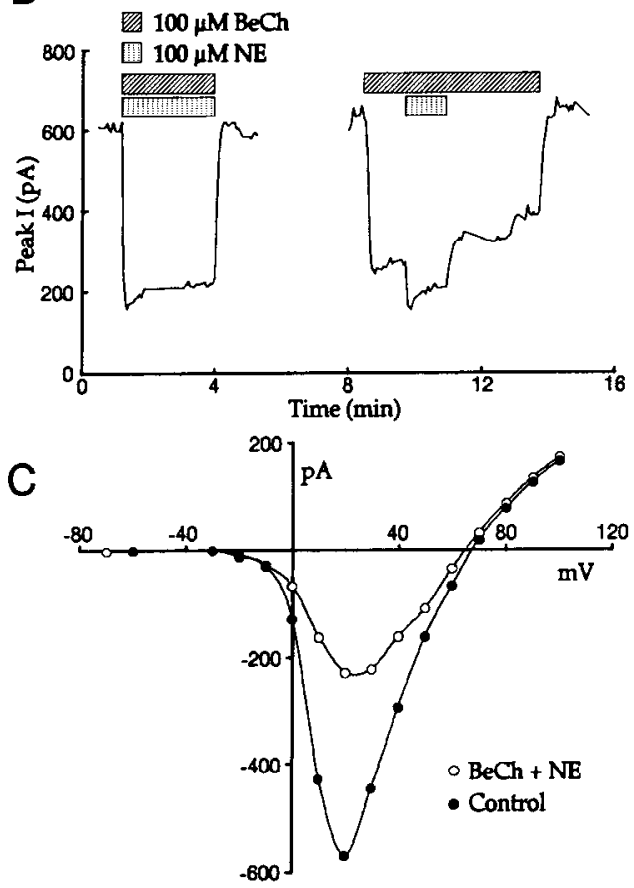

Figure 1. NE and $\mathrm{BeCh}$ reduce wholecell barium current in rat sympathetic neurons. $A$, Superimposed current traces obtained just before (control) and during bath application of $100 \mu \mathrm{M} \mathrm{BeCh}$ $(A I)$ or $100 \mu \mathrm{M}$ NE $(A 2)$ to the same SCG neuron. No other drugs were present. Voltage-clamp protocol is shown above the current traces. $\mathrm{Ba}(20 \mathrm{~mm})$ was the charge carrier. $B$, Plot of peak current amplitude versus time from a different cell. Same voltage protocol and conditions were used as in $A$, except that $1 \mu \mathrm{M}(+)-(S)-202-791$ was present in the bath throughout. Inhibition of the current by $\mathrm{NE}$ and $\mathrm{BeCh}$ occurs rapidly and reverses readily. The effects of $\mathrm{NE}$ and BeCh are only partially additive. $C$, Current-voltage relations from the same neuron as in $B$, measured in control solution (solid circles) and in the presence of both $\mathrm{NE}$ and $\mathrm{BeCh}$ (open circles). the inhibitory actions of cholinergic, GABAergic, and peptidergic transmitters on neuronal Ca currents (Dolphin and Scott, 1987; Hescheler et al., 1987; Wanke et al., 1987; Toselli and Lux, 1989). Consistent with our conclusion that the action of these transmitters occurs selectively on non-DHP-sensitive Ca channels, dialysis of SCG neurons with the nonhydrolyzable GTP analog GTP- $\gamma-S$ reduced the peak inward Ba current, but had no effect on the DHP-agonist-prolonged tail currents (Fig. $5 A$ ). As expected for a compound delivered to the cell by dialysis through the patch pipette, internal GTP- $\gamma-S$ acted more slowly than the neurotransmitters applied to the bath. However, the effects of GTP- $\gamma-\mathrm{S}$ became apparent within 1 min after formation of the whole-cell patch configuration and reached a steady state within a few minutes (Fig. 5). The actions of both adrenergic and cholinergic agonists could be accounted for by a pathway involving PTX-sensitive G-proteins. This is demonstrated in Figure $5 B$, where the percent reduction of peak Ba current is compared in control cells (circles) and in cells studied at various times after incubation in PTX (triangles). After $5 \mathrm{hr}$ of incubation in PTX, responses to $\mathrm{NE}$ or $\mathrm{BeCh}$ could no longer be elicited (Fig. 5B,C).

\section{$P K C$ is not a necessary link in transmitter action}

Rane and Dunlap (1986) first identified PKC as a necessary component in the cascade linking the action of $\mathrm{NE}$ to $\mathrm{Ca}$-channel inhibition in chick DRG neurons, but this role of PKC has
A

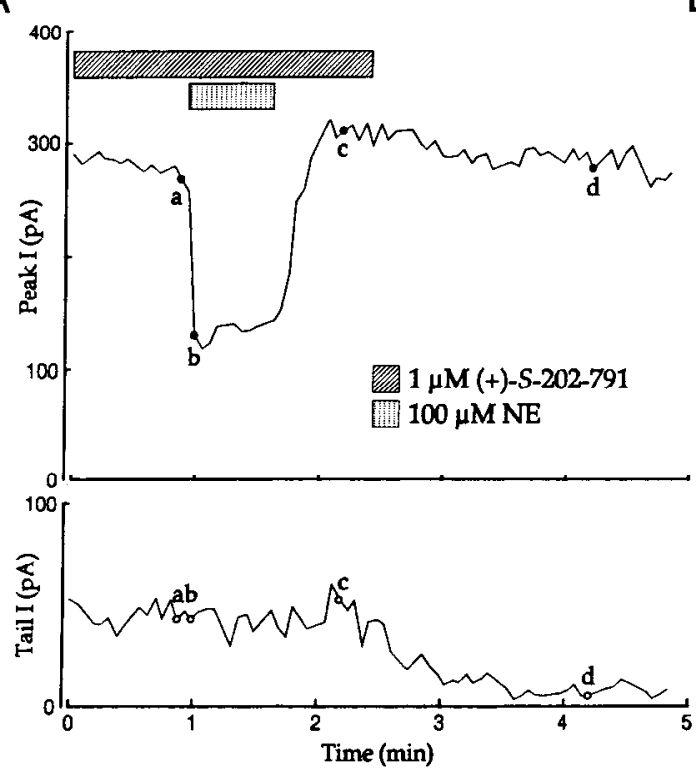

B

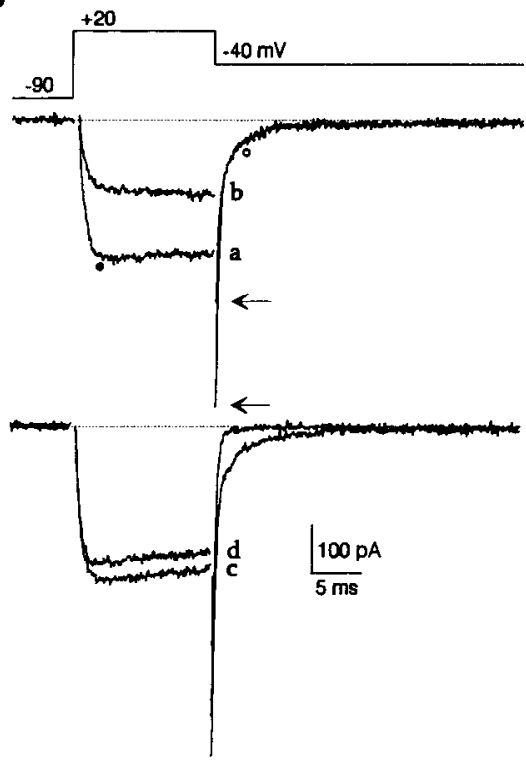

Figure 2. NE acts exclusively on the DHP-insensitive component of barium current. $A$, Time course of peak inward current at $+20 \mathrm{mV}($ top $)$ and of slow component of tail current measured 2.5 msec after repolarization to the tail potential of $-40 \mathrm{mV}$ (bottom). Presence of $(+)-(S)-202-791$ and NE in the bath is indicated by bars above the plot. $B$, Current traces taken at the time points $(a-d)$ indicated in $A$. Broken lines represent 0 current, and circles beneath the sweeps indicate the time at which peak (solid circle) and tail (open circle) currents were measured. Arrows point to the peak of the tail currents immediately following repolarization. 
A

Figure 3. NE has no effect on L-type calcium channels in the absence of the DHP agonist (+)-(S)-202-791. $A$, Time course of peak inward current during applications of $100 \mu \mathrm{M}$ NE before and after block of $N$-type channels by $10 \mu \mathrm{M}$ $\omega$-CgTx (indicated by bars above plot). $(+)-(S)-202-791$ is not present in the bath. Holding potential, $-50 \mathrm{mV}$; test potential, $+10 \mathrm{mV}$. Inset, Superimposed swceps taken at time points indicated $(a-d)$ show substantial reduction in current by NE before $\omega-\mathrm{CgTx}$, but no reduction of the L-type current remaining after $\omega$-CgTx. $B$, Combined measurements from several experiments of the percentage reduction in current produced by NE before (open bar $; n=7$ ) and after $\omega$-CgTx (solid bar; $n=7$ ) application. The results are shown as mean $\pm \mathrm{SEM}$.

$A$

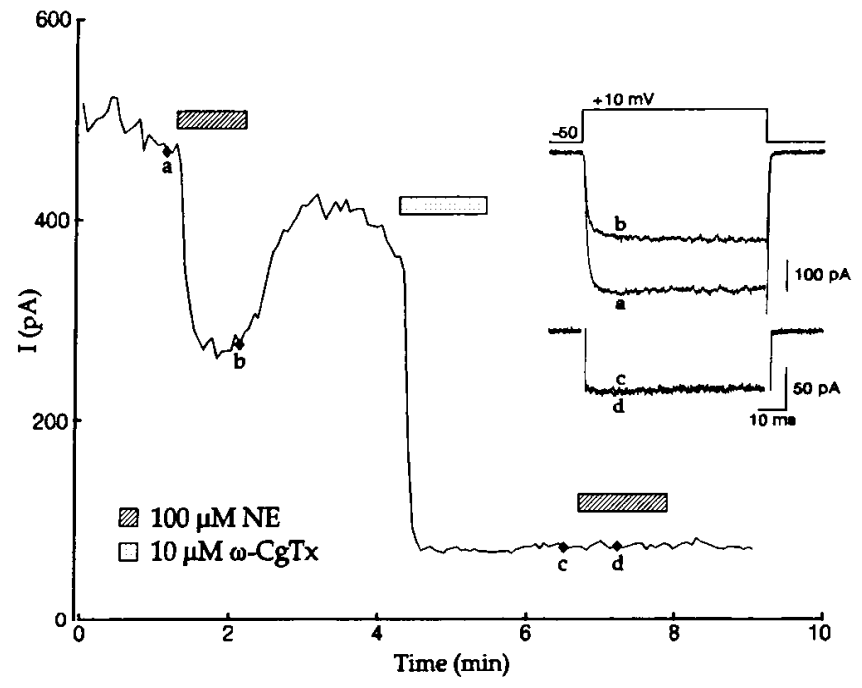

B

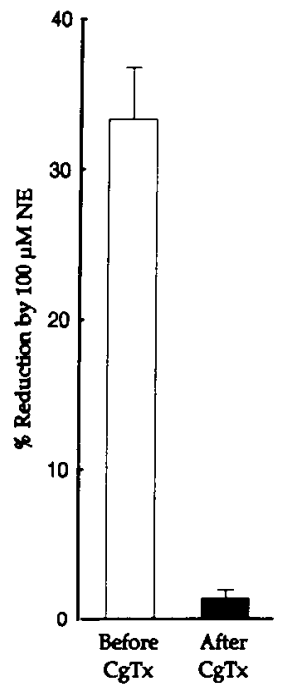

recently been questioned by Hockberger et al. (1989). We have used the PKC activator OAG and three different inhibitors to assess the role of PKC in the reduction of calcium currents by transmitters in rat SCG neurons.

The effects of OAG on Ca currents in SCG differed significantly from the transmitter actions described above. Like the transmitters, OAG markedly decreased whole-cell Ba currents, but the currents in the presence of OAG always decayed much more rapidly than the control currents (Fig. 6A), in striking contrast to the more slowly activating currents typically observed during application of the transmitters (Fig. 1; see also Marchetti et al., 1986; Wanke et al., 1987; Bean, 1989; Carbone and Lux, 1989; Plummer et al., 1989; Sah, 1990). More importantly, OAG reduced both the peak currents and the DHPagonist-prolonged tail currents (Fig. $6 \mathrm{C}$ ). The reduction of the slow tail current component by $\mathrm{OAG}$ and of the magnitude of the inhibition of the peak currents that are predominantly car- ried by $\mathrm{N}$-type channels in sympathetic neurons (see Jones and Marks, 1989; Plummer et al., 1989) strongly implies that the drug acts on both $\mathrm{L}$ - and N-type $\mathrm{Ca}$ channels. The relative inhibition produced with $\mathrm{OAG}$ was more variable than with any of the neurotransmitters tested. Most likely this variability was due to the difficulty of finding reproducible sonication conditions and the resulting variations in the concentration of dissolved OAG in our saline solutions (see Materials and Methods). In a total of nine cells, the peak inward current was decreased by $34.1 \pm 6.1 \%$, and the slow tail carried by DHP-sensitive channels was reduced by $34.5 \pm 6.9 \%$. The clear differences between the effects of $O A G$ and those of the transmitters raised doubt concerning the role of $\mathrm{PKC}$ in the mediation of the transmitter effects and prompted us to investigate more directly whether NE would remain effective in the presence of PKC inhibitors (Fig. 7). Incubation of neurons with the kinase inhibitor H-7 (Hidaka et al., 1984) for $1 \mathrm{hr}$ did not affect the
Figure 4. NPY affects barium current in a way similar to NE and BeCh. Time course of peak inward current at +10 $\mathrm{mV}$ (upper curve) and of slow component of tail current measured $6 \mathrm{msec}$ after repolarization to the tail potential of $-40 \mathrm{mV}$ (lower curve). Presence of (+)-(S)-202-791 and NPY in the bath is indicated by bars above the plot. Insets, Current traces taken at the time points indicated $(a-d)$ in time plots. Broken lines represent 0 current, and circles beneath the sweeps indicate the time at which peak (solid circle) and tail (open circle) currents were measured. Arrows point to the peak of the tail currents immediately following repolarization.

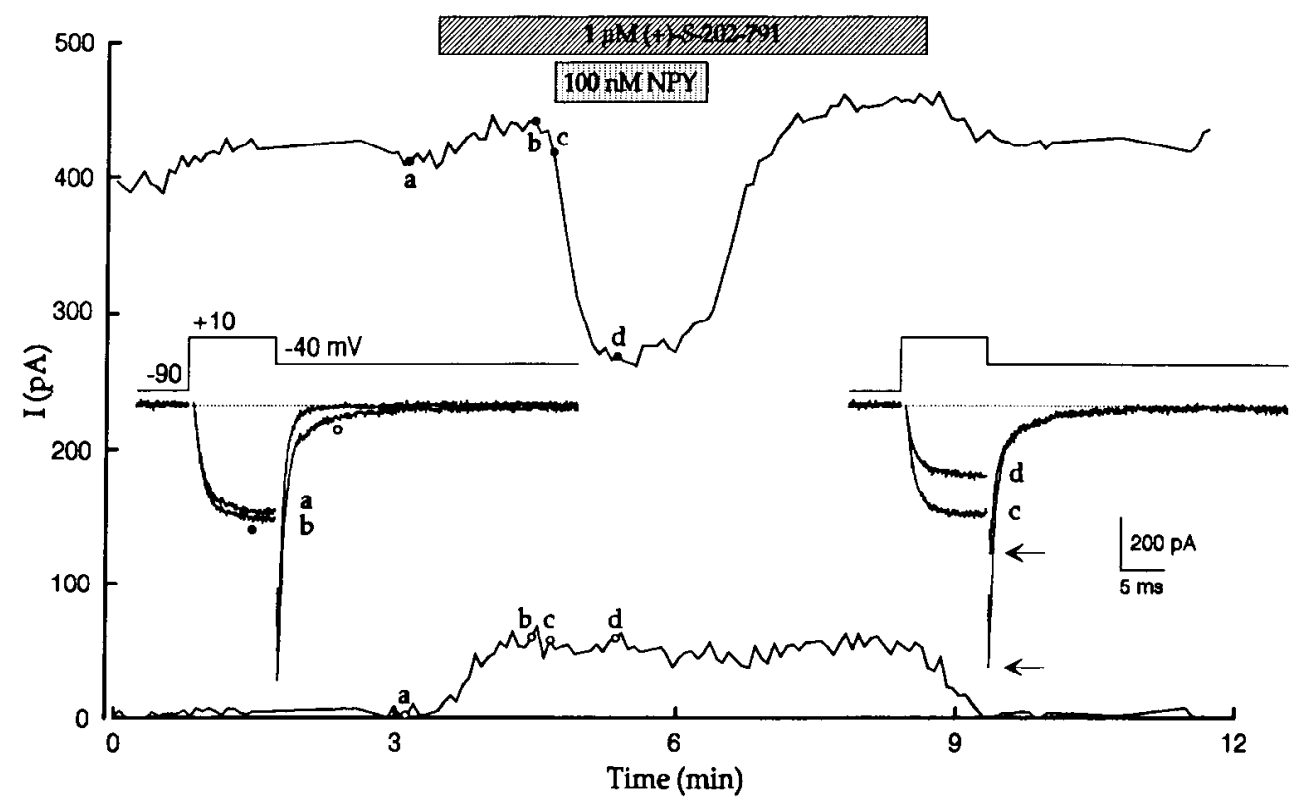




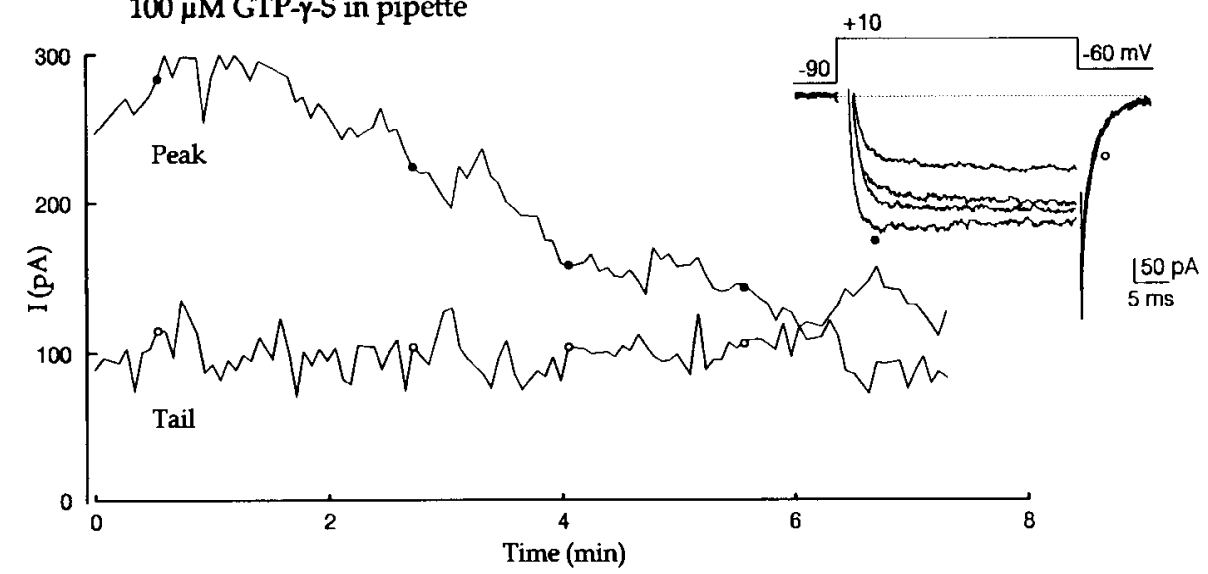

Figure 5. PTX-sensitive GTP-binding proteins mediate the effects of NE and BeCh. $A$, Effects of internal dialysis with GTP- $\gamma$-S on peak (upper curve) and slow tail currents (lower curve) in the presence of $1 \mu \mathrm{M}(+)-(S)-202-791$. The inset shows sweeps recorded at the times indicated (solid and open circles). In this experiment, TTX was absent from external recording solution, and this resulted in a large, rapidly inactivating outward current (carried by the internal

B

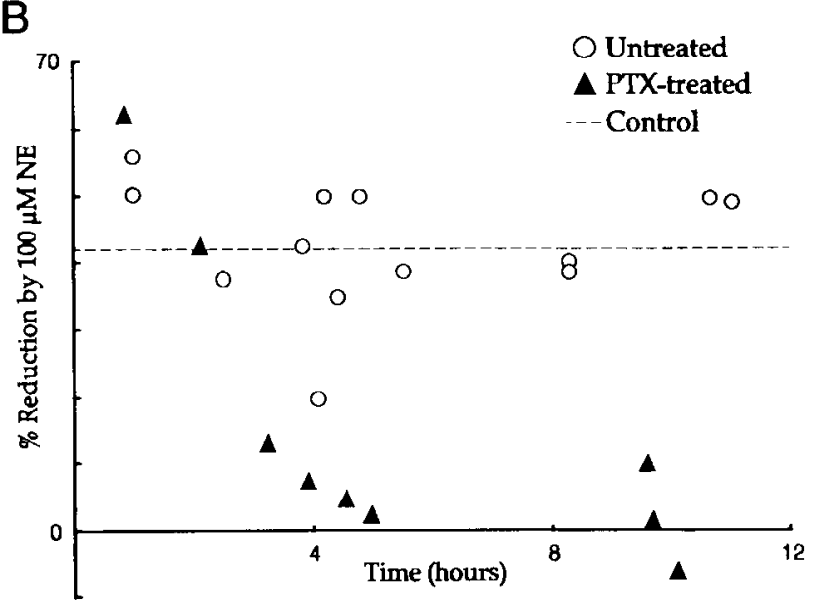

C

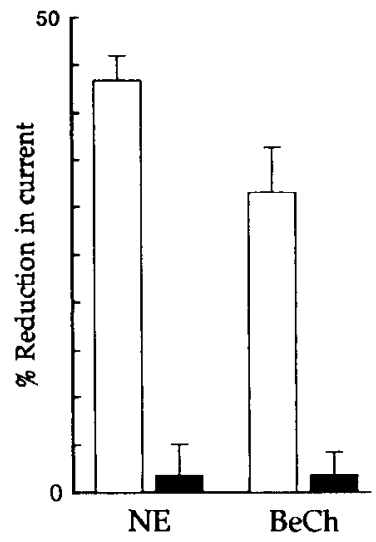
Cs ions), which has been removed from the sweeps shown in the inset. $B$, Measurements of the percentage reduction in current produced by NE taken at different times during incubation of cells with $500 \mathrm{ng} / \mathrm{ml}$ PTX. Each point indicates a recording from a different SCG neuron. Results from cells incubated only with carrier solution are shown as circles. Responses to NE from cells incubated with PTX are displayed as $t r i$ angles. The broken line indicates the average inhibition produced by NE in all control experiments in this study. $C$, Average reduction in current produced by NE or BeCh in untreated (open bars; $n=5,8)$ and PTX-treated cells (solid bars; $n=4,5$ ) after $5 \mathrm{hr}$ of incubation. The results are shown as mean \pm SEM.

reduction of current by NE $(47.97 \pm 3.9 \% ; n=12)$ when compared to control cells $(51.61 \pm 3.2 \% ; n=9$; Fig. $7 A)$. Pretreatment for $24 \mathrm{hr}$ with the PKC activator TPA (to downregulate PKC; Matthies et al., 1987) also had no significant effect on the amount of block by NE compared to controls [31.56 $\pm 3.6 \%$ $(n=9)$ vs. $25.59 \pm 1.9 \%(n=11)$, respectively; Fig. $7 A$ ]. Furthermore, we examined the effects of intracellular perfusion with the specific PKC inhibitor PKCI19-31 (House and Kemp, 1987; Ranc ct al., 1989). In Figurc $7 B$, cach sct of symbols shows data from a single cell that was repeatedly challenged by $100 \mu \mathrm{M} N E$ in experiments in which the internal solution (pipette solution) contained either 3 or $10 \mu \mathrm{M}$ PKCI19-31. It is clear that in all cells the response to $\mathrm{NE}$ remained intact and similar to the average response obtained with the control internal solution (broken line in Fig. 7B). It is particularly noteworthy that, even in cells in which repeated applications of NE could be obtained over more than $30 \mathrm{~min}$, the response to NE did not decrease with time.

\section{Summary of the modulatory effects on Ca currents in SCG}

Figure 8 presents the compiled results of the effects of the various agents tested on SCG Ba currents in this study. With the exception of OAG, which depressed both peak and DHP-prolonged tail currents equally, the other agents reduced only the peak currents and thus appear to be selective for non-DHPsensitive channels. The finding that clonidine was able to mimic the effects of NE implies that in rat SCG the adrenergic effects are mediated by an $\alpha_{2}$-adrenergic receptor. The greatest reduction of the peak currents was obtained with internal dialysis of GTP- $\gamma-\mathrm{S}$. Each neurotransmitter alone was significantly less effective than GTP- $\gamma-S$, and only the combination of cholinergic and adrenergic agonists produced inhibition approaching that of GTP- $\gamma-S$ in magnitude.

\section{Discussion}

The results presented in this article strongly suggest that in rat SCG neurons $\mathrm{N}$-type $\mathrm{Ca}$ channels are selectively inhibited by the actions of cholinergic and adrenergic agonists as well as by the peptide NPY. This conclusion is based mainly on the observation that tail currents carried by DHP-sensitive (L-type) Ca channels are not affected by the transmitters. Two alternative explanations for the resistance of tail currents to block by transmitters are unlikely: (1) The action of transmitters could be relieved at negative potentials. This possibility can be ruled out because the rapidly decaying tail currents carried by $\mathrm{N}$-type channels are blocked as effectively as the peak currents (Figs. $2 B, 3$ ), and because the blocking action of NE has been shown to be more potent at negative potentials (Bean, 1989). (2) The presence of the DHP agonist could somehow protect the L-type channels from block by the transmitters. This possibility was ruled out by showing that NE has no effect on L-type current even in the absence of DHPs (Fig. 3).

We feel that our experimental protocol represents a simple and clearly defined method of simultaneously assessing the sen- 
Figure 6. The effects of OAG on barium currents differ from those produced by NE, BeCh, NPY, or GTPbinding proteins. $A$, Superposition of control current (diamond) and current in the presence of $50 \mu \mathrm{M}$ OAG (star). $(+)-(S)-202-791(1 \mu \mathrm{M})$ was present in the external solution. Voltage protocol is shown above current traces. $B$, Peak current-voltage relationship obtained before and after addition of $50 \mu \mathrm{M} \mathrm{OAG}$ (same cell as in $A$ ). $C$. Time course of the effects of OAG on peak inward current (upper curve) and slow component of tail current (left, lower curve). (+)$(S)-202-791$ and OAG were present in the bath during times marked by bars above the plot. Current traces obtained at the times indicated $(a-d)$ are shown on expanded time scale (right). Voltage protocol is shown above current traces. Peak and tail currents were measured from the current traces at the times marked by a solid and open circle, respectively.
A
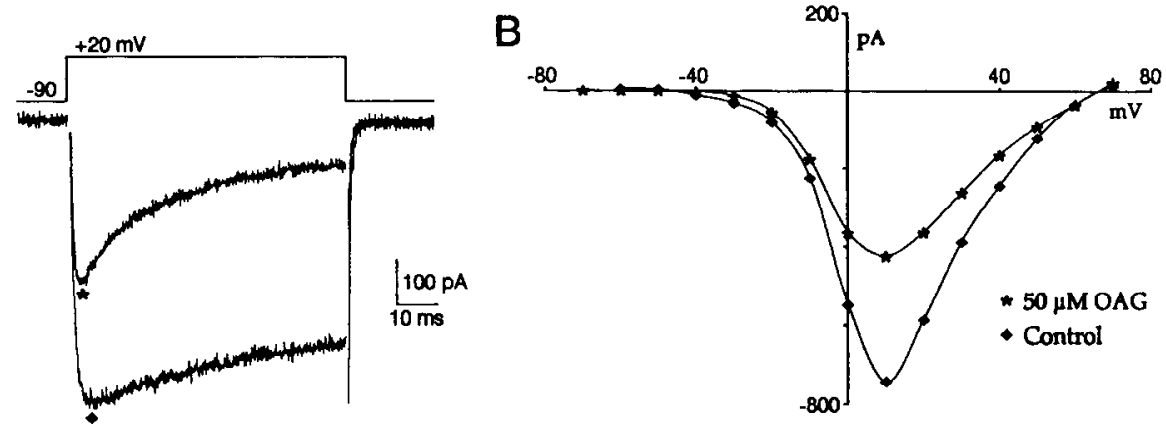

C
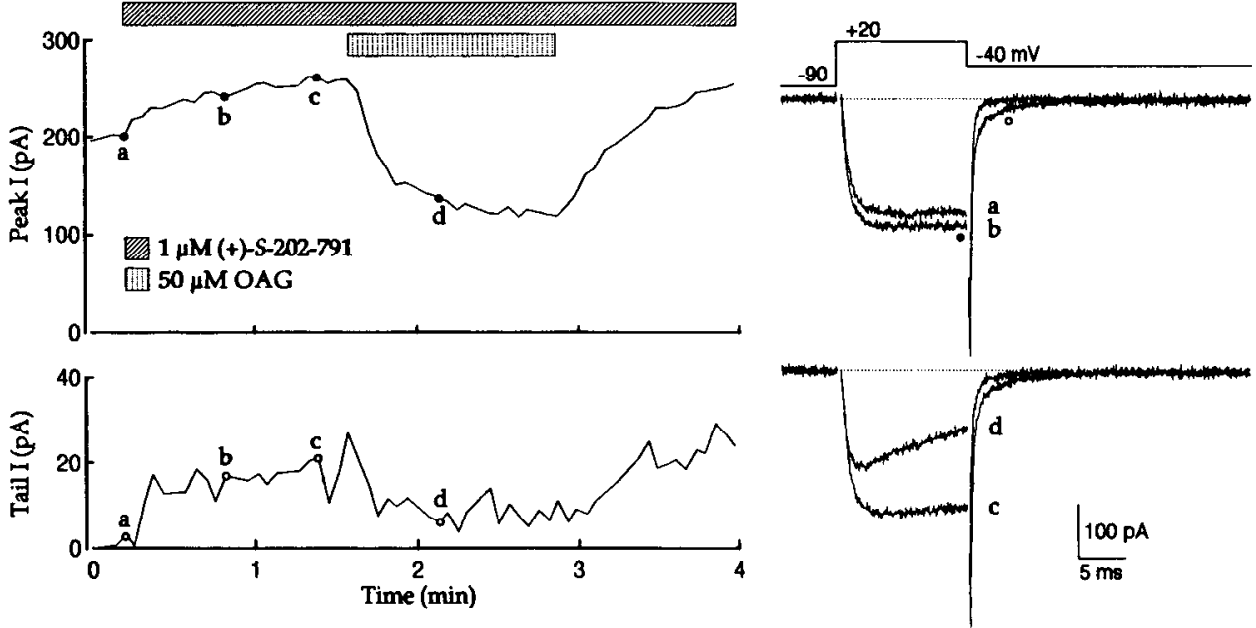

sitivities to transmitters and drugs of DHP-sensitive and -insensitive current components in whole-cell recordings. In principle, single-channel recordings would achieve the same goal with even less ambiguity. However, this approach is made difficult because even at the single-channel level identification of a particular Ca channel type is not trivial (Plummer et al., 1989), and particularly because transmitters like NE are only effective when added directly to the recording pipette (Forscher et al., 1986; Lipscombe et al., 1989). Therefore, studies of the action of $\mathrm{NE}$ at the single-channel level have so far been limited to comparisons across patches in either the presence or the absence of NE (Lipscombe et al., 1989). Unfortunately, patch-to-patch comparisons are likely to suffer from uncertainties because of the apparently very uneven distributions of Ca channels. In frog sympathetic neurons, for example, Lipscombe et al. (1988) found that hot spots of Ca channel activity, sometimes dominated by activity of just one channel type, were observed in half of their patches.

Our results, which show that NE acts selectively on N-type $\mathrm{Ca}$ channels in sympathetic neurons, are in agreement with the conclusions of Lipscombe et al. (1989). Our finding that internal GTP- $\gamma-\mathrm{S}$ also failed to affect L-type channels while it inhibited $N$-type channels leads us to postulate that all transmitter-induced reduction of $\mathrm{Ca}$ currents mediated by GTP-binding proteins may selectively occur through $\mathrm{N}$-type $\mathrm{Ca}$ channels in rat SCG neurons.

Unlike the present study, other workers have concluded that transmitters can have inhibitory effects on L-type channels (NE: Holz et al., 1986; Marchetti et al., 1986; ACh: Toselli and Lux, 1989; Wanke et al., 1989; NPY: Walker et al., 1988). Although this may reflect differences in cell types used, apparent effects on L-type channels may also have resulted from an inadequate separation of the whole-cell current components based on holding potential (Fig. 3; see also Plummer et al., 1989), which can lead to a misinterpretation of the effects of transmitters on $\mathrm{Ca}$ currents.

Because $\alpha_{1}$-adrenergic as well as muscarinic receptors can also be coupled to phospholipase C (for review, see Minneman, 1988; Hulme et al., 1990), receptor activation could result in inositol triphosphate-mediated $\mathrm{Ca}$ release from internal stores and inhibition of Ca currents through Ca-dependent inactivation. This mechanism was not the focus of our investigation and should be negligible under our experimental conditions (Ba as charge carrier, internal Ca chelators). Nevertheless, a remaining attenuated intracellular $\mathrm{Ca}$ transient could have produced the small, statistically insignificant decreases of L-type current tails observed with NE and BeCh (see Fig. 8).

Contrary to Song et al. (1989), who did not observe PTX sensitivity of cholinergic coupling to Ca currents in rat SCG, we found that cholincrgic as well as adrenergic effects are mediated by PTX-sensitive G-proteins. PTX sensitivity of cholinergic inhibition of rat SCG Ca currents has previously been described by Wanke et al. (1987). The virtually complete suppression of the effects of NE and BeCh by PTX suggests that no major additional signaling pathways exist that could bypass the coupling provided by PTX-sensitive G-proteins.

Neither NE nor GTP- $\gamma-S$ produced increases in the current component carried by L-type Ca channels. This might appear surprising given the well-established potentiating effects on cardiac L-type Ca channels of interventions that either increase 
A

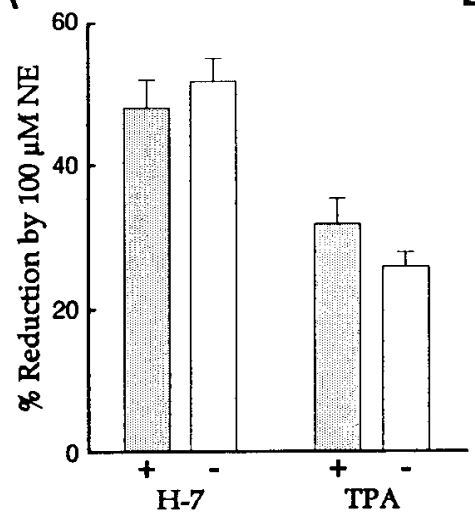

B

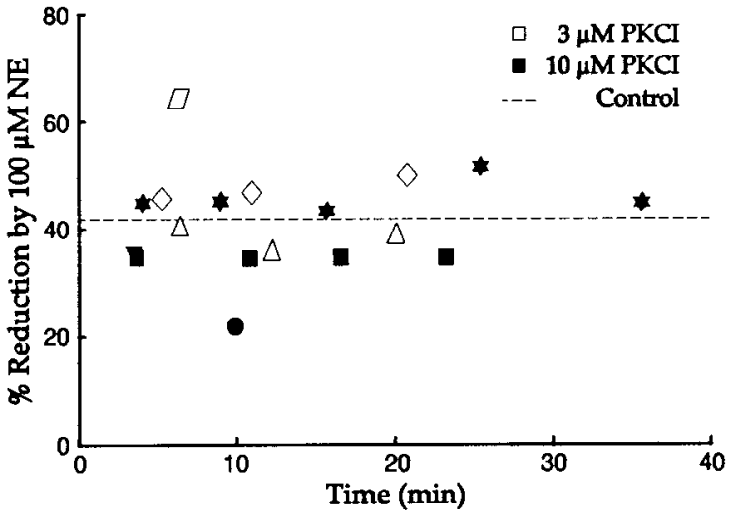

Figure 7. Inhibitors of PKC did not reduce the effectiveness of NE. $A$, Incubation for $1 \mathrm{hr}$ with $50 \mu \mathrm{M} \mathrm{H}-7$ or pretreatment for $24 \mathrm{hr}$ with $1 \mu \mathrm{M}$ TPA did not produce a significant change in the effectiveness of NE when compared to controls (two-tailed Student's $t$ test, $p>0.05$ ). Measurements shown as mean \pm SEM (H-7: $n=12,9$; TPA: $n=9,11$; experimental, control). The lower percentage of block seen in the experiment with TPA may have resulted from the enzymatic dissociation proccdurc used for these cells compared to the mechanical dissociation procedure used for all other neurons in this study. $B$, Plot of percent reduction in current produced by NE application at different times after establishment of whole-cell recording with PKCI19-31 in the pipette. Each set of symbols shows repeated bath applications of NE to the same cell. Open and solid symbols represent 3 and $10 \mu \mathrm{M}$ PKCI19-31 in the pipette, respectively. Broken line, mean effect of NE in all control experiments done in the absence of PKCI19-31. Holding potential, $-90 \mathrm{mV}$; test potential, $+10 \mathrm{mV} ; 20 \mathrm{~mm} \mathrm{Ba}$ as charge carrier.

cAMP (Cachelin et al., 1983; Brum et al., 1984; Tsien et al., 1986; Ochi and Kawashima, 1990) or may act directly through activated $\mathrm{G}_{\mathrm{s}}$-subunits (Yatani et al., 1987; Yatani and Brown, 1989; Shuba et al., 1990). Stimulatory effects of $\beta$-adrenergic agonists have also been reported on L-type Ca channels in frog sympathetic neurons (Lipscombe and Tsien, 1987) and on Ca channels in rat hippocampal neurons (Gray and Johnston, 1987). The presence of a DHP agonist should not have masked an effect mediated by cAMP or $G_{s}$, because DHP agonists and isoproterenol or $G_{s}$ have been shown to produce additive effects on L-type channels (Tsien et al., 1986; Yatani and Brown, 1989). It is highly unlikely that inhibitory effects on L-type channels in SCG neurons (mediated by PTX-sensitive G-proteins) could have just been offset by a stimulatory effect mediated by $\mathrm{G}_{\mathrm{s}}$ proteins. If this were the case, clonidine, which does not activate $\beta$-receptors and $\mathrm{G}_{s}$, should have produced a decrease of the DHP-sensitive tail currents. In addition, the $\alpha$-adrenergic block- ers phentolamine and yohimbine, which antagonized the effects of NE on N-type currents, did not unmask a potentiating effect of NE on L-type currents (data not shown).

Diversity in the receptor-effector coupling between mammalian and nonmammalian peripheral neurons is revealed when our results are compared with those of others obtained in frog or chick cells: (1) In frog sympathetic neurons, the coupling between receptors and $\mathrm{Ca}$ channels is provided by PTX-insensitive G-proteins, and neither muscarinic agonists nor NPY was effective (Bley and Tsien, 1990). (2) In contrast to our results and those of Schofield (1990), the $\alpha_{2}$-adrenergic agonist clonidine has been found to be ineffective in chicken DRG (Canfield and Dunlap, 1984) and frog sympathetic neurons (Lipscombe et al., 1989), leading these workers to postulate that the effects were mediated by an atypical $\alpha_{2}$-receptor. Apparently, the $\alpha_{2}$ receptor in rat SCG is of the "classical" pharmacological type.

Our conclusion that neurotransmitters that decrease neuronal

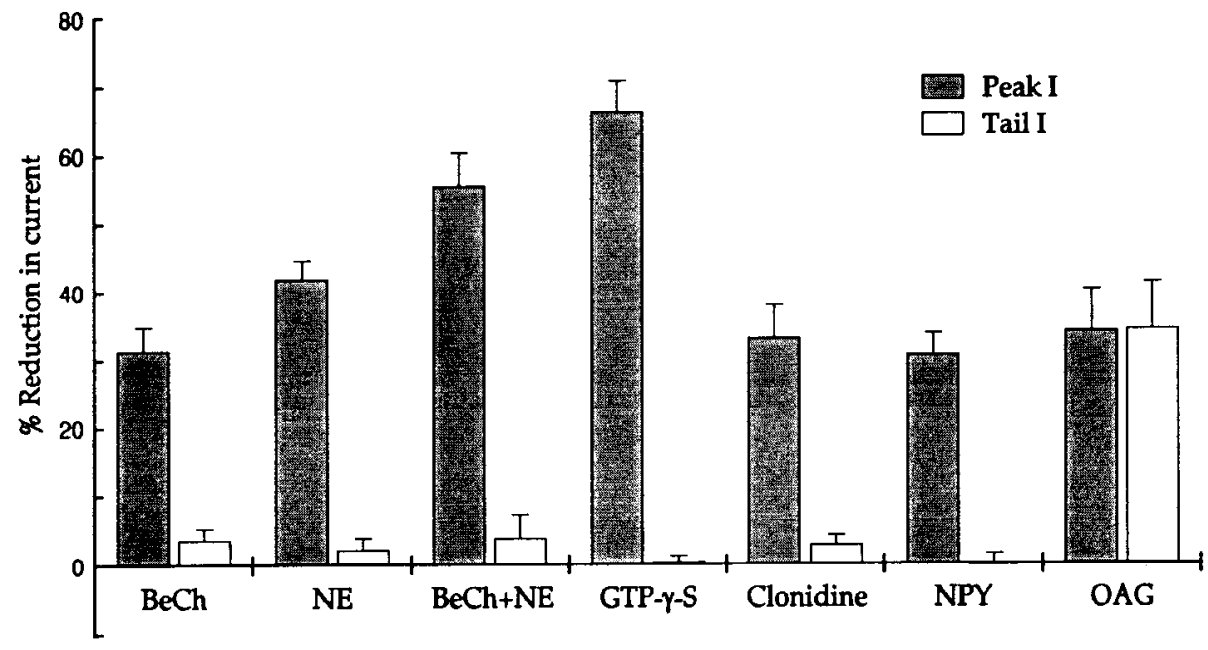

Figure 8. Adrenergic, cholinergic, and NPY-induced reduction in barium current is selective for the DHP-insensitive current, whercas OAG-induced reduction in current is nonselective. Solid and open bars represent the average reduction $( \pm$ SEM) produced by the substances indicated below each set of bars. Solid bars are peak currents, and open bars are tail currents measured as shown in Figures 2-5. Number of measurements (peak, tail, respectively): $100 \mu \mathrm{M}$ $\operatorname{BeCh}(N=24,8), 100 \mu \mathrm{M}$ NE $(N=26$, $11), 100 \mu \mathrm{M} \mathrm{BeCh}+100 \mu \mathrm{M} \mathrm{NE}(N=$ $8,7), 100 \mu \mathrm{M}$ GTP- $\gamma-\mathrm{S}(N=5,5), 100$ $\mu$ M clonidine $(N=5,5), 100$ nм NPY $(N=7,7), 50 \mu \mathrm{M}$ OAG $(N=9,9)$. All measurements made in the presence of $1 \mu \mathrm{M}(+)-(S)-202-791$. Two-tailed Student's $t$ tests indicated that only the effects of transmitters on peak current and the effect of OAG on tail current were sta!istically significant $(p<0.01)$. 
Ca currents spare L-type Ca channels is likely to be of significance for the actions of neurotransmitters released at effector organs by postganglionic sympathetic or parasympathetic neurons. Many of these organs rely on L-type Ca channels for their excitation (e.g., the cardiac sinus node, vascular and intestinal smooth muscle). It appears fitting that excitatory neurotransmitters like NE in heart and vascular smooth muscle, or ACh in intestinal smooth muscle, would not jeopardize their postsynaptic action by inhibiting the very channels that are involved in mediating the postsynaptic excitatory response. Because $\mathrm{N}$-type Ca channels appear to be neuron specific (Plummer et al., 1989), the inhibitory action of neurotransmitters on N-type $\mathrm{Ca}$ channels in autonomic nerves most probably occurs in the context of presynaptic inhibition, including autoinhibition, of neurotransmitter release, as pointed out previously by Hirning et al. (1988) and Lipscombe et al. (1989).

In rat SCG neurons, N-type Ca channels carry $80-85 \%$ of the peak inward Ba current, based on our previous studies of $\omega-\mathrm{CgTx}$ sensitivity and specificity (Plummer et al., 1989). Thus, even saturating concentrations of intcrnal GTP- $\gamma-S$ do not abolish all N-type current, consistent with the model of Bean (1989), in which $\mathrm{G}$-protein-mediated inhibition of $\mathrm{N}$-type current does not cause complete channel block but decreases the open probability in a voltage-dependent manner, thus changing the kinetics of the whole-cell and single-channel currents (Lipscombe et al., 1989).

A significant part of our study concerns an evaluation of the importance of $\mathrm{PKC}$ in the coupling of neurotransmitter action to $\mathrm{Ca}$ channel inhibition. Two aspects of the effects of $O A G$ strongly imply that this compound at the very least acts on $\mathrm{Ca}$ channels in rat SCG neurons by a pathway not shared by the neurotransmitters tested: (1) OAG reversibly decreased both Land N-type currents; (2) in contrast to the neurotransmitters, which slowed the apparent decay of the whole-cell current, OAG greatly accelerated the current decay. Furthermore, we regard the failure of $\mathrm{H}-7$, downregulation of PKC by TPA, and high concentrations of internally applied PKCI19-31 to block the NE response as strong evidence that in SCG neurons activation of $\mathrm{PKC}$ is not required for the coupling of the $\alpha_{2}$-receptor to the channel. For the intracellularly applied PKCI19-31, it would have been desirable to obtain direct proof that the peptide was reaching the cell. However, the following reasons make us confident that the observed lack of effect of PKCI19-31 on Ca current was not due to ineffective internal dialysis: (1) PKCI1931 has a molecular weight of 1500 and should theoretically diffuse readily into the small and process-free cells studied here $(\tau \simeq 1 \mathrm{~min}$, based on mean uncompensated series resistance of 6.43 M $\Omega$ and mean cell capacitance of $7.3 \mathrm{pF}$; Pusch and Neher, 1988). PKCI19-31 is only three times larger than GTP- $\gamma-S$, a substance that very rapidly produced effects during internal dialysis and reached a steady level within 5-10 min. (2) The pipette concentration of PKCI19-31 was 100 times higher than the in vitro $\mathrm{IC}_{50}$ for $\mathrm{PKC}$-dependent phosphorylation(House and Kemp, 1987). Thus, unless PKCI19-31 was bound extensively to cytoplasmic constituents or was rapidly degraded, we can expect rapid inhibition of PKC with our internal dialysis of PKCI1931. (3) The response to NE with PKCI19-31 in the pipette was not only similar to that in control solutions, but did not decrease during repeated applications in recordings lasting for more than 30 min. (4) Two independent methods of reducing PKC activity produced similar results. It is unclear why our findings differ from those of Rane et al. (1989), who reported attenuation of the response of Ca currents to NE and OAG in chick DRG cells with PKCI19-31 in the pipette, though they, like us, found no effect of $\mathrm{H}-7$ on the response to NE.

While our data on the effects of kinase inhibitors are at odds with those of Rane et al. (1989), our results are supported by those of Kasai and Aosaki (1989), who suggest that adenosine does not act via PKC-dependent pathways in chick DRG neurons. Furthermore, Hockberger et al. (1989) showed that the actions of OAG are not abolished by inhibitors of C-kinase and concluded that OAG and other lipid-soluble activators of PKC can have direct and nonspecific effects on Ca channels.

Our results obtained with OAG and kinase inhibitors do not rule out the possibility that $\mathrm{PKC}$ can modulate high-threshold neuronal Ca currents under certain experimental conditions (see, e.g., Lewis et al., 1986; Gross and Macdonald, 1988, 1989; Marchetti and Brown, 1988; Doerner et al., 1990). For example, Schroeder et al. (1990) reported that the effects of phorbol esters on $\mathrm{T}$-type Ca currents in rat $\mathrm{DRG}$ neurons can only be observed at temperatures higher than $30^{\circ} \mathrm{C}$. However, Schroeder et al. (1990) did not observe effects of phorbol esters on high-threshold Ca channels at any temperature and argue that the difference between their work and that of Rane et al. (1989) might reflect a species difference between rat and chick DRG neurons. A similar requirement for high temperatures has been described for the PKC-mediated modulation of a cardiac K-channel (Walsh and Kass, 1988). Other experimental conditions, such as the extent of the internal dialysis, also appear to be important in determining the effectiveness of PKC activators. For example, the potentiating action of phorbol esters on Ca currents in Aplysia bag cell neurons could only be observed under conditions in which the cells were not being dialyzed (DeRiemer et al., 1985). It was not the goal of our investigation to test whether PKC can modulate $\mathrm{Ca}$ channels in rat SCG neurons. Rather, we tested the hypothesis that activation of PKC is a necessary link in the signaling pathway between the $\alpha_{2}$-adrenergic receptor and the $\mathrm{N}$-type $\mathrm{Ca}$ channels, and we conclude that this signaling cascade does not require activation of PKC in rat SCG neurons.

\section{References}

Aosaki T, Kasai H (1989) Characterization of two kinds of highvoltage-activated Ca-channel currents in chick sensory neurons. Pfluegers Arch 414:150-156.

Bean BP (1989) Neurotransmitter inhibition of neuronal calcium currents by changes in channel voltage dependence. Nature $340: 153-$ 156.

Bley KR, Tsien RW (1990) Inhibition of $\mathrm{Ca}^{2+}$ and $\mathrm{K}^{+}$channels in sympathetic neurons by neuropeptides and other ganglionic transmitters. Neuron 4:379-391.

Brum G, Osterrieder W, Trautwein W (1984) $\beta$-Adrenergic increase in the calcium conductance of cardiac myocytes studicd with the patch clamp. Pfluegers Arch 401:111-118.

Cachelin AB, dePeyer JE, Kokubun S, Reuter H (1983) Calcium channel modulation by 8-bromo-cyclic AMP in cultured heart cells. Nature 304:402-404.

Canfield DR, Dunlap K (1984) Pharmacological characterization of amine receptors on embryonic chick sensory neurones. Br J Pharmacol 82:557-565.

Carbone E, Lux HD (1989) Modulation of Ca channels in peripheral neurons. Ann NY Acad Sci 560:346-357.

DeRiemer SA, Strong JA, Albert KA, Greengard P, Kaczmarek LK (1985) Enhancement of calcium current in Aplysia neurones by phorbol ester and protein kinase C. Nature 313:313-316.

Doerner D, Abdel-Latif M, Rogers TB, Alger BE (1990) Protein kinase C-dependent and -independent effects of phorbol esters on hippocampal calcium channel current. J Neurosci 10:1699-1706. 
Dolphin AC, Scott RH (1986) Inhibition of calcium currents in cultured rat dorsal root ganglion neurones by (-)-baclofen. $\mathrm{Br} \mathrm{J}$ Pharmacol 88:213-220.

Dolphin AC, Scott RH (1987) Calcium channel currents and their inhibition by $(-)$-baclofen rat sensory neurones: modulation by guanine nucleotides. J Physiol (Lond) 386:1-17.

Dunlap K, Fischbach GD (1981) Neurotransmitters decrease the calcium conductance activated by depolarization of embryonic chick sensory neurones. J Physiol (Lond) 317:519-535.

Ewald DA, Sternweis PC, Miller RJ (1988a) Guanine nucleotide-binding protein $\mathrm{G}_{0}$-induced coupling of neuropeptide $\mathrm{Y}$ receptors to $\mathrm{Ca}^{2+}$ channels in sensory neurons. Proc Natl Acad Sci USA 85:3633-3637.

Ewald DA, Matthies HJ, Perney TM, Walker MW, Miller RJ (1988b) The effect of down regulation of protein kinase $C$ on the inhibitory modulation of dorsal root ganglion neuron $\mathrm{Ca}^{2+}$ currents by neuropeptide Y. J Neurosci 8:2447-2451.

Forscher P, Oxford GS (1985) Modulation of calcium channels by norepinephrine in internally dialyzed avian sensory neurones. J Gen Physiol 85:743-763.

Forscher P, Oxford GS, Schulz D (1986) Noradrenaline modulates calcium channels in avian dorsal root ganglion cells through tight receptor-channel coupling. J Physiol (Lond) 379:131-144.

roucart S, Musgrave IF, Majewski H (1990) Inhibition of noradrenaline release by neuropeptide $Y$ does not involve protein kinase $C$ in mouse atria. Neuropeptides 15:179-185.

Fox AP, Nowycky MC, Tsien RW (1987a) Kinetic and pharmacological properties distinguishing three types of calcium currents in chick sensory neurones. J Physiol (Lond) 394:149-172.

Fox AP, Nowycky MC, Tsien RW (1987b) Single-channel recordings of three types of calcium channels in chick sensory neurones. J Physiol (Lond) 394:173-200.

Fried G, Lundberg JM, Theodorsson-Norheim E (1985a) Subcellular storage and axonal transport of neuropeptide Y (NPY) in relation to catecholamines in the cal. Acta Physiol Scand 125:145-154.

Fried G, Terenius L, Hokfelt T, Goldstein M (1985b) Evidence for differential localization of noradrenaline and neuropeptide $Y$ in neuronal storage vesicles isolated from rat vas deferens. J Neurosci 5: $450-458$

Grassi F, Lux HD (1989) Voltage-dependent GABA-induced modulation of calcium currents in chick sensory neurons. Neurosci Lett 105:113-119.

Gray R, Johnston D (1987) Noradrenaline and $\beta$-adrenoceptor agonists increase activity of voltage-dependent calcium channels in hippocampal neurons. Nature 327:620-622.

Gross RA, Macdonald RL (1987) Dynorphin A selectivity rcduces a large transient (N-type) calcium current of mouse dorsal root ganglion neurons in cell culture. Proc Natl Acad Sci USA 84:5469-5473.

Gross RA, Macdonald RL (1988) Reduction of the same calcium current component by $\mathrm{A}$ and $\mathrm{C}$ kinases: differential pertussis toxin sensitivity. Neurosci Lett 88:50-56.

Gross RA, Macdonald RL (1989) Activators of protein kinase C selectively enhance inactivation of a calcium current component of cultured sensory neurons in a pertussis toxin-sensitive manner. $J$ Neurophysiol 61:1259-1269.

Hamill OP, Marty A, Neher E, Sakmann B, Sigworth FJ (1981) Improved patch-clamp techniques for high-resolution current recording from cells and cell-free membrane patches. Pfluegers Arch 391:85100.

Hawrot E, Patterson PH (1979) Long-term culture of dissociated sympathetic neurons. Methods Enzymol 58:574-584.

Hescheler J, Rosenthal W, Trautwein W, Schultz G (1987) The GTPbinding protein, $G_{0}$, regulates neuronal calcium channels. Nature 325: 445-447.

Hidaka H, Inagaki M, Kawamoto S, Sasaki Y (1984) Isoquinolinesulfonamides, novel and potent inhibitors of cyclic nucleotide dependent protein kinase and protein kinase C. Biochemistry 23:50365041.

Hirning LD, Fox AP, McCleskey EW, Olivera BM, Thayer SA, Miller RJ, Tsien RW (1988) Dominant role of $\mathrm{N}$-type $\mathrm{Ca}^{2+}$ channels in evoked release of norepinephrine from sympathetic neurons. Science 239:57-61.

Hockberger P, Toselli M, Swandulla D, Lux HD (1989) A diacylglycerol analogue reduces neuronal calcium currents independently of protein kinase $C$ activation. Nature 338:340-342.

Holz GG IV, Rane SG, Dunlap K (1986) GTP-binding proteins me- diate transmitter inhibition of voltage-dependent calcium channels. Nature 319:670-672.

House C, Kemp BE (1987) Protein kinase C contains a pseudosubstrate prototope in its regulatory domain. Science 238:1726-1728.

Hulme EC, Birdsall NMJ, Buckley NJ (1990) Muscarinic receptor subtypes. Annu Rev Pharmacol Toxicol 30:633-673.

Ikeda SR, Schofield GG (1989) Somatostatin blocks a calcium current in rat sympathetic ganglion neurones. J Physiol (Lond) 409:221-240.

Jones SW, Marks TN (1989) Calcium currents in bullfrog sympathetic neurons. I. Activation kinetics and pharmacology. J Gen Physiol 94: 151-167.

Kasai H, Aosaki T (1989) Modulation of Ca-channel current by an adenosine analog mediated by GTP-binding protein in chick sensory neurons. Pfluegers Arch 414:145-149.

Lewis DL, Weight FF, Luini A (1986) A guanine nucleotide-binding protein mediates the inhibition of voltage-dependent calcium current by somatostatin in a pituitary cell line. Proc Natl Acad Sci USA 83: 9035-9039.

Lipscombe D, Tsien RW (1987) Noradrenaline inhibits N-type Ca channels in isolated frog sympathetic neurons. J Physiol (Lond) 390: $84 \mathrm{P}$.

Lipscombe D, Madison DV, Poenie M, Reuter H, Tsien RY, Tsien RW (1988) Spatial distribution of calcium channels and cytosolic calcium transients in growth cones and cell bodies of sympathetic neurons. Proc Natl Acad Sci USA 85:2398-2402.

Lipscombe D, Kongsamut S, Tsien RW (1989) $\alpha$-Adrenergic inhibition of sympathetic neurotransmitter release mediated by modulation of N-type calcium-channel gating. Nature 340:639-642.

Marchetti C, Brown AM (1988) Protein kinase activator 1-oleoyl-2acetyl-sn-glycerol inhibits two types of calcium currents in $\mathrm{GH} 3$ cells. Am J Physiol 254:C206-C210.

Marchetti C, Carbone E, Lux HD (1986) Effects of dopamine and noradrenaline on $\mathrm{Ca}$ channels of cultured sensory and sympathetic neurons of chick. Pfluegers Arch 406:104-111.

Matthies HJG, Palfrey HC, Lirning LD, Miller RJ (1987) Down regulation of protein kinase $\mathrm{C}$ in neuronal cells: effect on neurotransmitter release. J Neurosci 7:1198-1206.

McFadzean I, Mullaney I, Brown DA, Milligan G (1989) Antibodies to the GTP binding protein, $\mathrm{G}_{0}$, antagonize noradrenaline-induced calcium current inhibition in NG108- 15 hybrid cells. Neuron 3:177182.

Minneman KP (1988) $\alpha_{1}$-Adrenergic receptor subtypes, inositol phosphates, and sources of cell $\mathrm{Ca}^{2+}$. Pharmacol Rev 40:87-119.

Ochi R, Kawashima Y (1990) Modulation of slow gating process of calcium channels by isoprenaline in guinea-pig ventricular cells. $J$ Physiol (Lond) 424:187-204.

Plummer MR, Logothetis DE, Hess P (1989) Elementary properties and pharmacological sensitivities of calcium channels in mammalian peripheral neurons. Neuron 2:1453-1463.

Pusch M, Neher E (1988) Rates of diffusional exchange between small cells and a measuring patch pipette. Pfluegers Arch 411:204-211.

Rane SG, Dunlap K (1986) Kinase C activator 1,2-oleoylacetylglycerol attenuates voltage-dependent calcium current in sensory neurons. Proc Natl Acad Sci USA 83:184-188.

Rane SG, Walsh MP, McDonald JR, Dunlap K (1989) Specific inhibitors of protein kinase $\mathrm{C}$ block transmitter-induced modulation of sensory neuron calcium current. Neuron 3:239-245.

Rosenthal W, Hescheler J, Trautwein W, Schultz G (1988) Receptorand G-protein-mediated modulations of voltage-dependent calcium channels. Cold Spring Harbor Symp Quant Biol 53:247-254.

Sah DWY (1990) Neurotransmitter modulation of calcium current in rat spinal cord neurons. J Neurosci 10:136-141.

Schofield GG (1990) Norepinephrine blocks a calcium current of adult rat sympathetic neurons via an $\alpha_{2}$-adrenoccptor. Eur J Pharmacol $180: 37-47$

Schofield GG, Ikeda SR (1988) Neuropeptide Y blocks a calcium current in $\mathrm{C}$ cells of bullfrog sympathetic ganglia. Eur $\mathrm{J}$ Pharmacol 151:131-134.

Schroeder JE, Fischbach PS, McCleskey EW (1990) T-type calcium channels: heterogeneous expression in rat sensory neurons and selective modulation by phorbol esters. J Neurosci 10:947-951.

Shuba YM, Hesslinger B, Trautwein W, McDonald TF, Pelzer D (1990) Whole-cell calcium current in guinea-pig ventricular myocytes dialysed with guanine nucleotides. J Physiol (Lond) 424:205-228.

Song S-Y, Saito K, Noguchi K, Konishi S (1989) Different GTP- 
binding proteins mediate regulation of calcium channels by acetylcholine and noradrenaline in rat sympathetic ncurons. Brain Res 494: 383-386.

Toselli M, Lux HD (1989) GTP-binding proteins mediate acetylcholine inhibition of voltage dependent calcium channels in hippocampal neurons. Pfluegers Arch 413:319-321.

Tsien RW, Bean BP, Hess P, Lansman JB, Nilius B, Nowycky MC (1986) Mechanisms of calcium channel modulation by beta-adrenergic agents and dihydropyridine calcium agonists. J Mol Cell Cardiol 18:691-710.

Walker MW, Ewald DA, Perney TM, Miller RJ (1988) Neuropeptide $\mathrm{Y}$ modulates neurotransmitter release and $\mathrm{Ca}^{2+}$ currents in rat sensory neurons. J Neurosci 8:2438-2446.

Walsh KB, Kass RS (1988) Regulation of a heart potassium channel by protein kinase A and C. Science 242:67-69.
Wanke E, Ferroni A, Malgaroli A, Ambrosini A, Pozzan T, Meldolesi J (1987) Activation of a muscarinic receptor selectively inhibits a rapidly inactivated $\mathrm{Ca}^{2+}$ current in rat sympathetic neurons. Proc Natl Acad Sci USA 84:4313-4317.

Wanke E, Sardini A, Ferroni A (1989) L and N Ca ${ }^{21}$ channels coupled to muscarinic receptors in rat sensory neurons. Ann NY Acad Sci 560:398-400.

Yatani A, Brown AM (1989) Kapid $\beta$-adrenergic modulation of cardiac calcium channel currents by a fast $G$ protein pathway. Science 245:71-74

Yatani A, Codina J, Imoto Y, Reeves JP, Birnbaumer L, Brown AM (1987) A G protein directly regulates mammalian cardiac calcium channels. Science 238:1288-1292. 